National Marine

Fisheries Service

NOAA
Fishery Bulletin

a established in 1881 a
Spencer F. Baird

First U.S. Commissione of Fisheries and founder of Fishery Bulletin
Abstract-Demersal fish inhabiting continental slopes experience colder temperatures, increasing hydrostatic pressure, decreasing oxygen saturation, and decreasing productivity with increased depth. We examined depth-related patterns in smalland large-scale movement, growth, and relative survival of sablefish (Anoplopoma fimbria) tagged during 1996-2004 in Oregon waters at depths of 141-1225 m; 2614 of 17,400 fish were recaptured as of December 2016. Recapture rates indicated significant size-dependent mortality. Discard mortality was affected by surface temperature for small fish $(<55 \mathrm{~cm}$ in fork length [FL]) from upper slope depths $(<400$ $m)$. Depth effects on recapture rates reflected differences in fishing effort. Most recaptures were near the initial capture depth. Although 91\% of the recaptures were within 200 $\mathrm{km}$ of the tagging location, some individuals migrated thousands of kilometers, reaching the western Aleutian Islands. Growth rates were faster for females than for males and decreased with depth. Sablefish in the deepest depths sampled had extremely slow growth rates $(<2 \mathrm{~cm}$ FL/year), low dispersal (2.4\%), and were largely female (81\%). Prior studies of age distribution indicate that deep slope habitats also support greater longevity, potentially providing a refuge for older fish and a buffering effect to longevity overfishing, depending on spatial differences in exploitation rates.

Manuscript submitted 10 April 2016. Manuscript accepted 24 February 2017. Fish. Bull. 115:233-251 (2017).

Online publication date: 24 March 2017. doi: 10.7755/FB.115.2.10

The views and opinions expressed or implied in this article are those of the author (or authors) and do not necessarily reflect the position of the National Marine Fisheries Service, NOAA.

\title{
Patterns of movement, growth, and survival of adult sablefish (Anoplopoma fimbria) at contrasting depths in slope waters off Oregon
}

\author{
Susan M. Sogard (contact author) ${ }^{1}$ \\ Steven A. Berkeley² \\ Email address for contact author: susan.sogard@noaa.gov \\ 1 Fisheries Ecology Division \\ Southwest Fisheries Science Center \\ National Marine Fisheries Service, NOAA \\ 110 McAllister Way \\ Santa Cruz, California 95060 \\ ${ }^{2}$ Long Marine Laboratory \\ University of California \\ 100 McAllister Way \\ Santa Cruz, California 95060
}

Sablefish occupy a remarkably broad geographic range in outer shelf and slope waters of the northern Pacific Ocean, from southern Baja California around the Pacific Rim to the coast of Japan (Hart, 1973). Mature adults typically occur at depths $>100$ $\mathrm{m}$, and some occur at depths $>2700$ $\mathrm{m}$ (Beamish et al. ${ }^{1}$ ). Sablefish are broadcast spawners, releasing eggs at slope depths from January through March in waters of British Columbia, Canada (Mason et al., 1983), and from November through March in Oregon waters (Macewicz and Hunter, 1994). Larval and early juvenile stages occur in the neuston (upper few meters) layer (Shenker, 1988). In southeast Alaska and British Columbia waters, juveniles often migrate inshore and occupy shallow bays and sounds (Rutecki and Varosi, 1997). From Washington through California, juveniles settle to demersal habitats but typically remain offshore (Heyamoto and Alton, 1965). Adults have

\footnotetext{
${ }^{1}$ Beamish, R. J., C. Houle, C .Wood, and R. Scarsbrook. 1979. A summary of sablefish tagging and exploratory trapping studies conducted during 1978 by the Pacific Biological Station. Can. Data Rep. Fish. Aquat. Sci. 162, 113 p. [Available from website.]
}

slow growth, low mortality, and life spans up to 114 years (Beamish and McFarlane, 2000). Much of the adult habitat occurs along a depth gradient of decreasing oxygen saturation, decreasing temperatures, and decreasing productivity.

The sablefish population is thought to comprise 2 stocks: a northern or Alaska stock, ranging from northwest Vancouver Island through the Aleutian Islands and Bering Sea to Japan, and a southern or west coast stock, ranging from southwest Vancouver Island to Baja California (Kimura et al., 1998). The 2 stocks differ in growth rates and life history parameters, including size and age at maturity. Northern fish attain larger asymptotic sizes, estimated as 67.7 $\mathrm{cm}$ in fork length (FL) for males and $80.1 \mathrm{~cm}$ FL for females (Echave et al., 2012), whereas estimates for southern fish are $56.3 \mathrm{~cm}$ FL for males and $64.2 \mathrm{~cm} \mathrm{FL}$ for females (Johnson et al. ${ }^{2}$ ); however, there is considerable

2 Johnson, K. F., M. B. Rudd, M. Pons, C. A. Akselrud, Q. Lee, F. Hurtado-Ferro, M. A. Haltuch, and O. S. Hamel. 2016. Status of the U.S. sablefish resource in 2015, 176 p. Pacific Fishery Management Council, Portland, OR. [Available from website.] 
variability within regions and by depth (Echave et al., 2012; Head et al., 2014). Size and age at maturity have also been found to differ with latitude and depth; for females in the southern stock, Head et al. (2014) estimated 50\% maturity at ages of 4.9-11 years and lengths of $48.5-58.5 \mathrm{~cm}$ FL.

The separation between sablefish stocks along the coast of Vancouver Island occurs at the boundary between the California Current upwelling ecosystem to the south and the Gulf of Alaska downwelling ecosystem to the north. The associated differences in a broad suite of oceanographic factors are likely to affect sablefish biology. Genotypic differentiation, however, is weak (Tripp-Valdez et al., 2012), indicating significant exchange between the 2 stocks of fish. Prior tagging studies have reported small but persistent migrations from Alaska to west coast waters and vice versa (Fujioka et al., 1988; Kimura et al., 1998; Echave et al., 2013).

\section{Patterns in depth distribution}

The broad bathymetric distribution of sablefish is thought to arise from an ontogenetic migration to progressively deeper depths with age, on the basis of increasing proportions of mature fish at greater depths (Fujiwara and Hankin, 1988), increasing mean length with depth (Hunter et al., 1989), and increasing abundances of older or larger fish with depth (Saunders et al., 1997; Sigler et al., 1997; Jacobson et al., 2001; Head et al., 2014; Johnson et al. ${ }^{2}$ ). Maloney and Sigler (2008) examined depth changes of tagged juveniles and found a clear pattern of movement to deeper waters by age 3 and a decline in occurrence at depths $<500 \mathrm{~m}$ as fish aged. However, at ages from 3 to 20 years the largest concentration of each age class was at depths of 500$700 \mathrm{~m}$. Kimura et al. (1998) compared depth at initial capture with depth at recapture and found that northern fish congregated at depths of 400-800 m, whereas southern fish were more likely to be recaptured in the same depth zone as that of tagging.

An alternative to the hypothesis of ontogenetic migration to deeper habitats was proposed by Norris (1997), who suggested that different depth distributions are a consequence of adaptive radiation of enzyme systems and differing physiological efficiency at different depths depending on genotype. Under this scenario, upon reaching sexual maturity, adults of different ecotypes migrate to depth ranges appropriate to their physiology and then remain at those depths. Fujiwara and Hankin (1988) likewise suggested the possibility of depth-related population structure for sablefish in California on the basis of contrasting maturity schedules.

The depth range of adult sablefish includes the persistent oxygen minimum zone (OMZ) present along the eastern Pacific slope. Gilly et al. (2013) defined the OMZ as waters with dissolved oxygen levels $<20 \mathrm{\mu mol} /$ $\mathrm{kg}$, or approximately $10 \%$ of the saturation of oxygen in surface waters. The position of the OMZ varies latitudinally, but along the Oregon coast it spans depths of about 500-1500 $\mathrm{m}$ and is enveloped by an oxygen limited zone of slightly higher dissolved oxygen concentrations (Pierce et al., 2012; Gilly et al., 2013). Sablefish residing within the OMZ appear to be well adapted to the harsh physical conditions and potentially limited food availability of deep slope habitats (Sullivan and Smith, 1982; Drazen, 2007).

\section{Spatial movement patterns}

Spatial movements of sablefish have been extensively documented in tag-recapture studies. Within the northern stock, multiple studies spanning several decades have found widespread movement away from the location of tagging and that the likelihood of movement increases from southeast Alaska waters through the central Gulf of Alaska and into the Aleutian Islands and Bering Sea (reviews in Echave et al., 2013; Hanselman et al., 2015). In contrast, southern sablefish exhibit more limited movement away from the general tagging location (Fujioka et al., 1988; Kimura et al., 1998). Movement patterns of fish tagged in British Columbia waters suggest a more limited dispersal from southern tagging locations than from northern tagging locations (Beamish and McFarlane, 1988; McFarlane and Saunders, 1997).

\section{Growth}

Age-0 sablefish exhibit extremely rapid growth rates (Boehlert and Yoklavich, 1985; Sigler et al., 2001; Sogard and Olla, 2001; Sogard, 2011), but growth slows markedly in mature adults, and fish reach asymptotic size within their first decade (Johnson et al. ${ }^{2}$ ). Males grow more slowly than females (McFarlane and Beamish, 1983; Sasaki, 1985; Kimura et al., 1993; Saunders et al., 1997; Echave et al., 2012; Morita et al., 2012), and northern fish appear to have faster growth rates and attain larger sizes than southern fish (Kimura et al., 1993; Kimura, 2008). Depth-related differences in growth rates are suggested by the pattern of smaller size-at-age with depth (Saunders et al., 1997; Head et al., 2014).

\section{Management impacts}

The southern stock has been heavily exploited since the $1970 \mathrm{~s}$, although regulations have reduced annual landings to $<10,000$ metric tons (t) in recent years (Johnson et al. $^{2}$ ). In conjunction with a size-related price structure, discarding of smaller fish was common practice. Although sablefish lack swimbladders and do not suffer barotrauma, they are susceptible to the rapid temperature increases associated with capture in cold, deep water and retrieval to warm surface waters. Mortality rates in experiments simulating capture at $4-6^{\circ} \mathrm{C}$ and discarding at surface temperatures 


\section{Table 1}

Releases of tagged sablefish (Anoplopoma fimbria) off Newport, Oregon, from February 1996 to May 1998 (tagging set 1), with gear used, depth of sampling (in meters), surface temperature, fish sizes (measured in fork length [FL]), number of fish tagged, and number of fish recaptured for each sampling trip.

\begin{tabular}{|c|c|c|c|c|c|c|c|}
\hline & \multicolumn{7}{|c|}{ Trip (month/year) } \\
\hline & $2 / 96$ & $3 / 96$ & $5 / 96$ & $6 / 96$ & $10 / 96$ & $9 / 97$ & $5 / 98$ \\
\hline Gear & Trawl & Trawl & Trawl & Trawl and pot & Pot & Trawl & Trawl \\
\hline $\begin{array}{l}\text { Depth range } \\
\quad \text { (and mean) }\end{array}$ & $\begin{array}{c}371-644 \\
(460)\end{array}$ & $\begin{array}{l}431-565 \\
\quad(506)\end{array}$ & $\begin{array}{l}221-293 \\
\quad(240)\end{array}$ & $\begin{array}{c}141-631 \\
(214)\end{array}$ & $\begin{array}{l}421-581 \\
\quad(503)\end{array}$ & $\begin{array}{l}227-649 \\
\quad(347)\end{array}$ & $\begin{array}{c}221-406 \\
(265)\end{array}$ \\
\hline Mean surface temperature $\left({ }^{\circ} \mathrm{C}\right)$ & 12.2 & 11.4 & 12.9 & 14.4 & 14.3 & 18.3 & 12.7 \\
\hline Number of fish tagged & 42 & 139 & 2221 & $\begin{array}{c}3002 \\
(2913 \text { trawl, } 89 \text { pot })\end{array}$ & 1977 & 48 & 80 \\
\hline Size range (cm FL) & $40.8-77.9$ & $46.8-75.9$ & $34.8-83.5$ & $30.7-81.5$ & $44.5-83.5$ & $41.4-80.3$ & $41.9-81.0$ \\
\hline Mean size (cm FL) & 56.2 & 54.3 & 48.1 & 49.7 & 57.8 & 54.3 & 53.6 \\
\hline $\begin{array}{l}\text { Number of recaptured fish and } \\
\text { percentage of total fish tagged }\end{array}$ & $\begin{array}{c}5 \\
(11.9 \%)\end{array}$ & $\begin{array}{c}24 \\
(17.3 \%)\end{array}$ & $\begin{array}{c}322 \\
(14.5 \%)\end{array}$ & $\begin{array}{c}393 \\
(13.1 \%)\end{array}$ & $\begin{array}{c}489 \\
(24.7 \%)\end{array}$ & $\begin{array}{c}8 \\
(16.7 \%)\end{array}$ & $\begin{array}{c}13 \\
(16.2 \%)\end{array}$ \\
\hline
\end{tabular}

of $12-20^{\circ} \mathrm{C}$ indicate that discarded fish may fare poorly during periods of elevated surface temperatures (Olla et al., 1998; Davis et al., 2001). The additional stress imposed on fish caught in deeper waters may also increase discard mortality rates. Current management objectives have resulted in a greater spread of fishing effort throughout the year, but survival of discarded fish remains a concern in stock assessments. For example, total discards in the southern stock in 2013 were approximately $755 \mathrm{t}$, and applied mortality rates were $20 \%$ for fixed-gear fisheries and $50 \%$ for trawl fisheries (Somers et al., 2014).

\section{Objectives}

Our objectives were to examine patterns of movement, growth, and survival for sablefish residing in slope waters off central Oregon. We examined small-scale movements among depths and large-scale movements associated with long distance migrations, comparing the latter to prior studies of the 2 sablefish stocks. Tagging of fish captured at discrete depths and contrasting surface temperatures allowed us to examine the potential effects of temperature and depth on discard mortality. Growth rates were compared by depth and in relation to migration distances. All patterns were compared in relation to initial fish size, sex, and time at large, where possible.

\section{Materials and methods}

\section{Fish capture and tagging}

All tagging was conducted off Newport, Oregon. For the first tagging event (tagging set 1), fish were captured primarily in trawls from 4 chartered fishing vessels during 8 trips from February 1996 to May 1998 (Table
1). Fish were measured, tagged with a uniquely numbered Floy FD-943 nylon spaghetti tag (Floy Tag Inc., Seattle, WA) inserted on the left side just beneath the anterior end of the first dorsal fin, and immediately released. The goal of this tagging effort was to provide data for a preliminary evaluation of growth, as well as small- and large-scale movements. Boat captains selected fishing locations to maximize the number of fish available for tagging. A range of depths along the outer shelf and upper slope was sampled, with depths clustered within 2 groups, designated as depth zone 1 , which represented fish captured at depths of 141-302 $\mathrm{m}$, and depth zone 2 , which represented fish captured at depths of 335-649 m.

For tagging set 2 , fish were captured with pots deployed from 1 vessel at 2 depth ranges (327-366 $\mathrm{m}$ and 1112-1225 m) during 2 trips with expected warm (September 2003) and cool (May 2004) surface temperatures (Table 2). Depths were designated as depth zone 2 (to match tagging set 1 ) and depth zone 3 . One objective of the sampling design was to test for effects of depth and surface temperature on discard mortality. The numbers of fish tagged were evenly distributed among the 4 depth and surface temperature combinations to provide a balanced design. Surface temperatures were measured during tagging, and bottom temperatures were estimated with the Simple Ocean Data Assimilation data set (Carton et al., 2005) and obtained from the Environmental Research Division Data Access Program server of the NOAA Southwest Fisheries Science Center (website).

Recaptured fish were reported by commercial fishermen, observers, and processors, with varying levels of information. For each analysis described below, re-

\footnotetext{
${ }^{3}$ Mention of trade names or commercial companies is for identification purposes only and does not imply endorsement by the National Marine Fisheries Service, NOAA.
} 


\section{Table 2}

Releases of tagged sablefish (Anoplopoma fimbria) off Newport, Oregon, in September 2003 and May 2004 (tagging set 2), with mean depth of sampling, surface temperature, fish sizes (measured in fork length [FL]), number of fish tagged, and number of fish recaptured for each sampling trip. All fish were captured with pots from the same vessel.

\begin{tabular}{|c|c|c|c|c|}
\hline & \multicolumn{4}{|c|}{ Trip (month/year and depth zone) } \\
\hline & 9/03 zone 2 & 9/03 zone 3 & $5 / 04$ zone 2 & 5/04 zone 3 \\
\hline Mean depth (m) & 355 & 1145 & 353 & 1163 \\
\hline \multicolumn{5}{|l|}{ Surface temperature } \\
\hline category and mean & Warm, $15.9^{\circ} \mathrm{C}$ & Warm, $16.9^{\circ} \mathrm{C}$ & Cool, $14.6^{\circ} \mathrm{C}$ & $\mathrm{Cool}, 14.5^{\circ} \mathrm{C}$ \\
\hline Number of fish tagged & 2460 & 2486 & 2463 & 2482 \\
\hline Size range (cm FL) & $42.5-85.5$ & $44.0-90.0$ & $44.5-78.0$ & $46.5-87.5$ \\
\hline Mean size (cm FL) & 54.3 & 57.7 & 57.4 & 60.1 \\
\hline \multicolumn{5}{|l|}{ Number of recaptured fish } \\
\hline and percentage of total tagged & $435(17.7 \%)$ & $140(5.6 \%)$ & $594(24.1 \%)$ & $191(7.7 \%)$ \\
\hline
\end{tabular}

capture data were used depending on the availability and precision of information reported. Sample sizes are noted for each analysis in the results section. Where practical, recaptures from both tagging sets were combined for analysis.

\section{Data analysis}

The potential roles of fish size and initial capture depth on the probability of recapture were tested with logistic regressions conducted separately for each tagging set and by using the following equation:

$$
\operatorname{Logit}(P(x))=\alpha+\beta_{1} X_{1}+\beta_{2} X_{2},
$$

where $P(x)=$ probability of recapture;

$X_{1}=$ initial fish length (continuous variable);

$X_{2}=$ depth zone of initial capture (categorical variable);

$\alpha=$ a constant; and

$\beta=$ a coefficient.

For tagging set 2, additional logistic regressions tested recapture rates between warm and cool surface temperatures (categorical variable) at the time of tagging. Initial inspection of these data suggested that surface temperature effects were more evident in smaller fish; therefore, logistic regressions were conducted separately for small $(<55 \mathrm{~cm} \mathrm{FL})$, medium $(55-65 \mathrm{~cm} \mathrm{FL})$ and large (>65 cm FL) size classes within each depth zone. These categories correspond with the size groups tested by Davis et al. (2001) for the rate of body core temperature increase after transfer to warmer water. Regressions for comparisons of recapture probability by surface temperature were calculated with this equation:

$$
\operatorname{Logit}(P(x))=\alpha+\beta_{1} X_{1},
$$

where $X_{1}=$ a temperature category.
For all logistic regressions, the Wald statistic was used to determine significance of each coefficient.

Analysis of small-scale movement among depths was possible for 1762 fish. We used analyses of covariance (ANCOVAs) calculated separately by initial depth zone to test for effects of recapture season (spawning: from November through April and nonspawning: from May through October) on recapture depth, with fish size and time at large included as covariates.

For recaptured fish with location coordinates, great circle distances from tagging to recapture location were calculated. We divided recaptured fish into residents, defined as fish recaptured within $200 \mathrm{~km}$ of their tagging locations, and "dispersers," fish recaptured >200 $\mathrm{km}$ from their tagging locations, according to Beamish and McFarlane (1988). Fish without precise location coordinates could be categorized as dispersers or residents on the basis of the general area of recapture; for example, fish caught in Alaska waters were dispersers regardless of their exact capture location. Using chi-square association tests and analysis of variance (ANOVA), we examined characteristics of these fish to determine whether the tendency to make long migrations from the tagging location was influenced by fish size, sex, or the depth of initial capture. We used linear regression to determine whether the proportion of fish dispersing was affected by the time at large.

We compared the growth of individuals whose recapture length and sex had been recorded, as well as recapture depth and gear used. Growth was expected to be influenced by fish size, with smaller fish growing at a faster rate than larger fish, and by time at large, with growth rate decreasing as the time at large increased. To select an appropriate growth model we first considered several age-based models that have been reparameterized for size-based application to tag-recapture data, including von Bertalanffy, Gompertz, and Schnute growth models, as described by Francis (1995), and a nonlinear regression model described for sable- 
fish by Kimura et al. (1998). All produced comparable results that defined the roles of initial size and time at large on growth. Because our objective was to assess potential effects of different environmental factors, we elected to use the nonlinear regression approach, which provided a simple means of incorporating additional parameters into the model and evaluating their influence. We anticipated that depth would influence growth rates, with reduced growth at the deepest depths sampled due to low temperatures, low oxygen levels, and low food availability. We also anticipated that recapture gear could affect growth because Kimura et al. (1993) had observed higher growth for sablefish caught in pots than in trawls. Preliminary analyses indicated that growth of fish recaptured by longline was similar to that of fish recaptured in pots; therefore, the groups of fish captured by the 2 fixed gears were combined for comparison with fish recaptured in trawls.

We used a "best subsets" approach to evaluate the potential role of independent variables in growth, first including all factors in the nonlinear regression, then estimating subset models with individual factors removed. Because the growth model was not based on an explicit likelihood calculation, it was not readily adaptable to the commonly used Akaike information criterion approach for model comparison. Therefore, Mallows's $C_{p}$ (Mallows, 1973), an appropriate metric of model fit for least squares regression, was calculated to compare among different formulations of the model in order to evaluate support for the different potential explanatory variables. The full model, with 6 parameters, was based on the following equation:

$$
\begin{gathered}
F L 2=F L 1+\text { days } * \exp \left(\beta_{1} * F L 1\right. \\
+\beta_{2} * \text { days }+\beta_{3} * \text { sex }+\beta_{4} * \text { depth } 1 \\
\left.+\beta_{5} * \text { depth } 2+\beta_{6} * \text { gear }\right),
\end{gathered}
$$

where $F L 1$ = initial fork length;

$F L 2=$ recapture fork length;

days = days at large;

sex $=$ a dummy variable for sex $(0=$ female, $1=$ male);

depth1 = depth at initial capture;

depth 2 = depth at recapture;

gear $=$ a dummy variable for recapture gear $(0=$ fixed, $1=$ trawl); and all $\beta$ are coefficients.

We then evaluated all possible subset models with 1-5 parameters and calculated Mallows's $C_{\mathrm{p}}$ for each to evaluate how well each model balanced parsimony and fit to the data. The full model has $C_{\mathrm{p}}$ equal to the number of parameters by definition, whereas subset models that adequately account for variance in the data set but with fewer parameters will have a $C_{\mathrm{p}}$ that closely matches their reduced number of parameters. We examined the $C_{\mathrm{p}}$ values to determine if a simpler model (i.e., one with fewer parameters) was appropriate for describing growth differences.

We also examined growth of dispersing individuals to determine whether their growth rates differed from those of fish categorized as residents and whether growth varied with the distance moved. We used residuals from the full growth model in ANOVAs, conducted separately by sex, to first compare growth of dispersing fish with growth of resident fish. For the dispersers only, linear regressions were then used to compare growth with the distance moved.

All statistical analyses were performed with SYSTAT, vers. 13, software (Systat Software Inc., San Jose, CA).

\section{Results}

\section{Initial size distributions}

Size distributions at tagging differed by depth zone (Figs. 1 and 2). For the first set (1996-1998), 5291 fish were tagged from depth zone 1 and 2218 fish from depth zone 2. For the second set (2003-2004), 4923 fish were tagged from zone 2 and 4968 from zone 3 . In zone 1 there were 2 clear size modes at $34 \mathrm{~cm}$ and $44 \mathrm{~cm}$ FL (tagging set 1, Fig. 1) that were not present in the deeper zones. In zones 2 and 3 , fish sizes followed a continuum, likely representing a broad range of fish ages. Modal size was larger ( $57 \mathrm{~cm} \mathrm{FL)} \mathrm{in} \mathrm{zone} 3$ than in zone $2(54 \mathrm{~cm} \mathrm{FL})$. Very large fish $(\geq 70 \mathrm{~cm} \mathrm{FL})$ occurred at all depths but were relatively rare overall, with $n=56$ in zone 1 (1.1\% of total), $n=130$ in zone 2 $(1.8 \%)$ and $n=47$ in zone $3(0.9 \%)$.

For both tagging sets combined, sex was determined for 690 recaptured fish. The sex ratio varied with initial capture depth, ranging from 58\% females in depth zone 1 to $62 \%$ in depth zone 2 and $81 \%$ in depth zone 3 , indicating an increasing bias toward females at increasing depths.

\section{Probability of recapture}

In total, 2614 tagged fish were recaptured up to December 2016, with 1254 (16.7\%) from tagging set 1 and $1360(13.7 \%)$ from tagging set 2 . The potential roles of fish size and initial capture depth on the probability of recapture were tested with logistic regressions, conducted separately for each tagging set. For tagging set 1 , recapture rates increased with fish size (Wald statistic: $10.4, P<0.001)$ and were greater in depth zone 2 , with $23.6 \%$ fish recaptured, than in zone 1, with $13.8 \%$ fish recaptured (Wald statistic: $4.4, P<0.001$ ). For tagging set 2 , recaptures again increased with fish size (Wald statistic: $13.7, P<0.001$ ), but were greater in zone $2(20.9 \%)$ than in zone $3(6.7 \%$, Wald statistic: 22.1 , $P<0.001$ ).

One of the objectives with tagging set 2 was to determine whether discard mortality is influenced by depth of capture or by the temperature gradient experienced by fish captured in cold deep waters and released in warm surface waters. Tagging set 1 was not included in this comparison because of limited sampling at warm surface temperatures and deeper depths. For tagging set 2 , recapture rates differed markedly between depth 


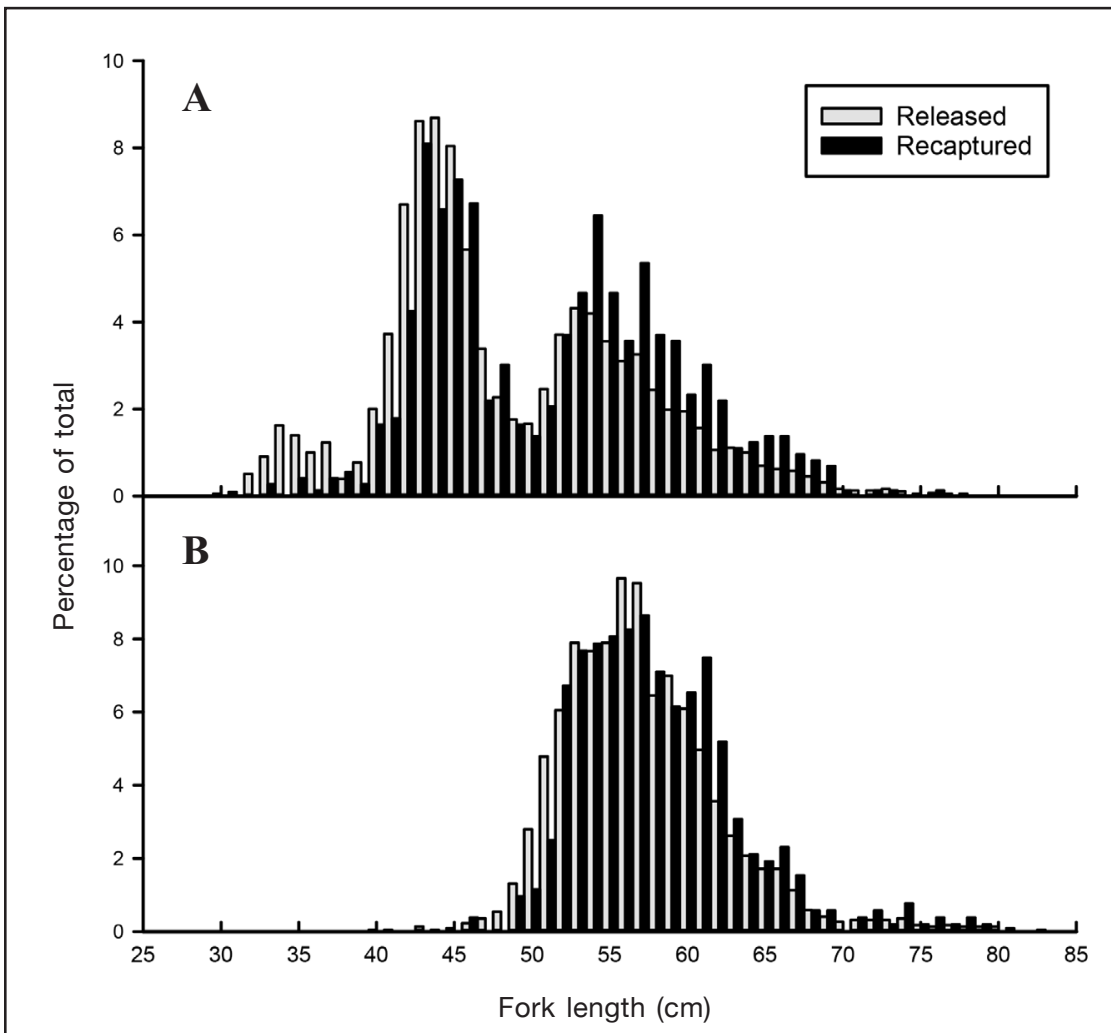

Figure 1

Initial size distributions as a percentage of the total number of fish for tagged (released) and recaptured sablefish (Anoplopoma fimbria) captured in shelf and slope waters off Newport, Oregon, from February 1996 to May 1998 (tagging set 1). Fish were divided into 2 groups on the basis of initial depth of capture: (A) depth zone 1 (141-302 m) and (B) depth zone 2 (335-649 m).

zones; therefore, the effects of surface temperature were evaluated separately for each depth category. Using logistic regressions, we compared recapture rates, by warm and cool surface temperature categories, for each size group of small, medium, and large fish within each depth zone. A significant difference for zone 2 fish was found only for small fish, with the probability of recapture increasing when surface temperatures at tagging were cooler (Table 3; Wald statistic: 4.4, $P<0.001)$. For fish initially captured in zone 3 , there were no significant differences between recapture rates of small, medium, or large fish for the tagging temperature categories. However, the sample size for small fish was only a total of 25 recaptured fish and therefore limits our confidence in this result.

\section{Small-scale movements among depths}

Fish initially captured in depth zone 1 tended to be recaptured at deeper depths, with recaptures at depths from 124 to $1207 \mathrm{~m}$ (Figs. 3 and 4). However, $55 \%$ of the recaptures were at depths within $200 \mathrm{~m}$ of the initial capture depth. Fish were recaptured at greater depths during the spawning season (from November through April) than during the nonspawning season (ANCOVA: $F_{1,438}=26.6, P<0.001$ ). Recapture depths increased with time at large $\left(F_{1,438}=29.4\right.$, $P<0.001)$ but did not differ with fish size $\left(F_{1,438}=1.8\right.$, $P=0.184)$. Fish initially captured in depth zone 2 were recaptured at depths from 73 to $1220 \mathrm{~m}$; however, $86 \%$ of the recaptures were within $200 \mathrm{~m}$ of the initial depth. As observed for fish from depth zone 1 , depth of recapture was greater during the spawning vs. nonspawning season (ANOVA: $F_{1,1054}=68.1$, $P<0.001)$, recapture depth increased with time at large $\left(F_{1,1054}=64.4, P<0.001\right)$, and there was no effect of initial fish size $\left(F_{1,1054}=3.0, P=0.081\right)$. Fish initially captured in zone 3 tended to be recaptured near their original depth or shallower, at depths from 238 to $1280 \mathrm{~m} ; 56 \%$ were recaptured within $200 \mathrm{~m}$ of their initial depth. In contrast to the result for fish from the shallower depth zones, recapture depth of zone 3 fish did not differ by season (ANOVA: $F_{1,253}=0.2, P=0.698$ ). Recaptures tended to be deeper with both increasing time at large $\left(F_{1,253}=83.6, P<0.001\right)$, and with larger initial fish size $\left(F_{1,253}=27.6, P<0.001\right)$. 
Table 3

Results of logistic regressions for comparing recapture rates of small ( $<55 \mathrm{~cm}$ in fork length [FL]), medium (55-65 $\mathrm{cm} \mathrm{FL}$ ), and large ( $>65 \mathrm{~cm} \mathrm{FL)} \mathrm{sablefish} \mathrm{(Anoplopoma} \mathrm{fimbria)} \mathrm{initially} \mathrm{captured} \mathrm{off} \mathrm{Newport,} \mathrm{Oregon,} \mathrm{in} \mathrm{depth}$ zones 2 (mean depth: $354 \mathrm{~m}$ ) and 3 (mean depth: $1154 \mathrm{~m}$ ) at warm (mean $16.4^{\circ} \mathrm{C}$ ) and cool (mean $14.5^{\circ} \mathrm{C}$ ) surface temperatures for tagging set 2 (September 2003 and May 2004).

\begin{tabular}{lccccccc}
\hline Size class & $\begin{array}{c}\text { Depth } \\
\text { zone }\end{array}$ & $\begin{array}{c}\text { Number } \\
\text { tagged at } \\
\text { warm temp. }\end{array}$ & $\begin{array}{c}\text { Number }(\%) \\
\text { recaptured at } \\
\text { warm temp. }\end{array}$ & $\begin{array}{c}\text { Number } \\
\text { tagged at } \\
\text { cool temp. }\end{array}$ & $\begin{array}{c}\text { Number }(\%) \\
\text { recaptured at } \\
\text { cool temp. }\end{array}$ & $\begin{array}{c}\text { Wald } \\
\text { statistic }\end{array}$ & $P$ \\
\hline Small & 2 & 1608 & $183(11.4 \%)$ & 726 & $131(18.0 \%)$ & 4.3 & $<0.001$ \\
Small & 3 & 674 & $17(2.5 \%)$ & 208 & $8(3.8 \%)$ & 1.0 & 0.314 \\
Medium & 2 & 693 & $207(29.9 \%)$ & 1571 & $417(26.5 \%)$ & 1.6 & 0.111 \\
Medium & 3 & 1635 & $105(6.4 \%)$ & 1886 & $132(7.0 \%)$ & 0.7 & 0.496 \\
Large & 2 & 156 & $45(28.8 \%)$ & 165 & $46(27.9 \%)$ & 0.2 & 0.847 \\
Large & 3 & 172 & $18(10.5 \%)$ & 370 & $50(13.5 \%)$ & 1.0 & 0.320 \\
\end{tabular}

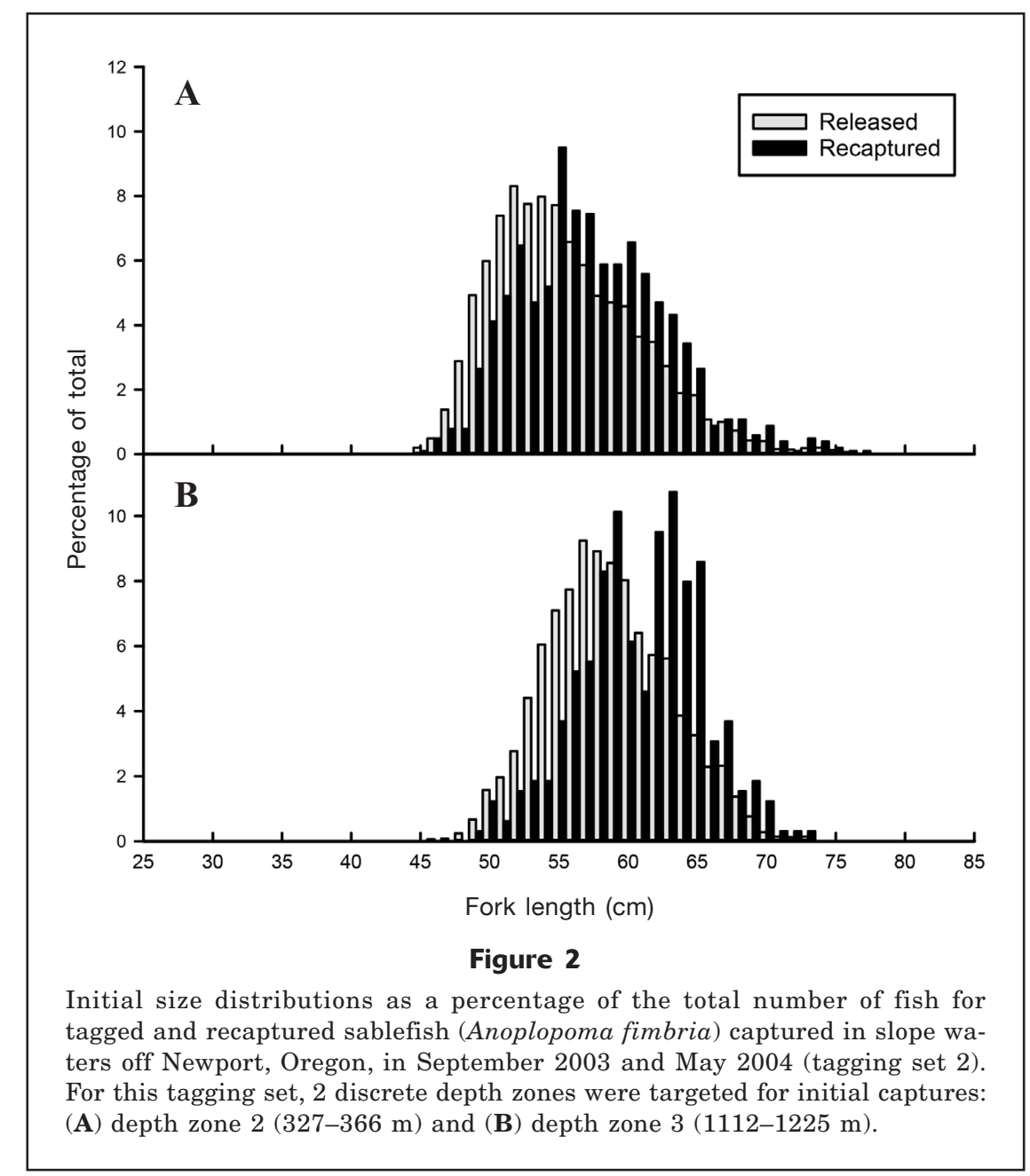

\section{Large-scale movements}

For both sets of tagging combined, 2566 recaptured fish had sufficient location information to categorize them as dispersers or resident fish (recaptured $>200$ $\mathrm{km}$ or $<200 \mathrm{~km}$ from the tagging location, respectively). Dispersers composed only $9 \%$ of these fish. Of the fish whose sex was reported, there was a marginal but 


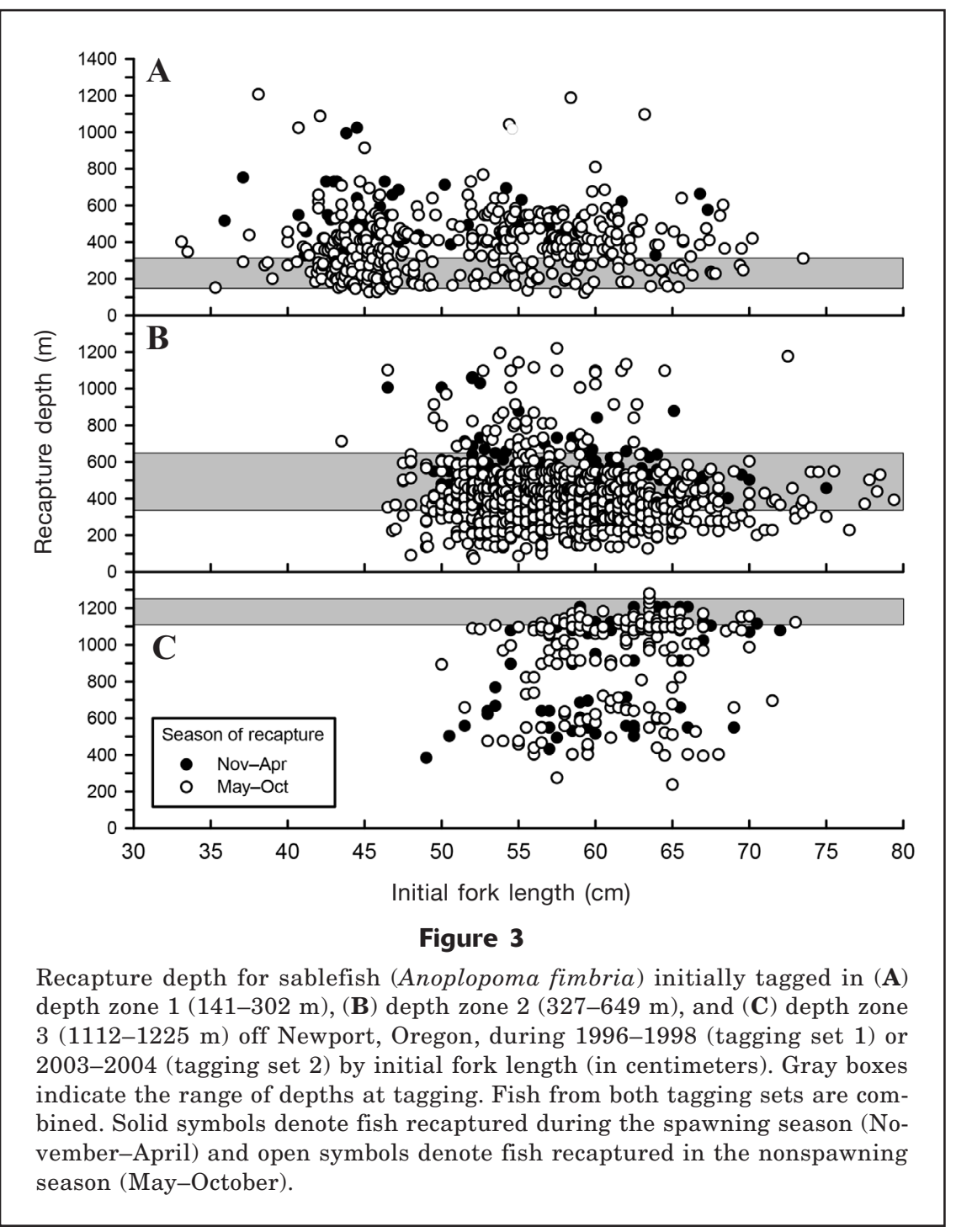

nonsignificant trend for females to be more likely to disperse than males $\left(\chi^{2}=3.47, P=0.062\right)$. In contrast, depth of initial capture had a highly significant effect, with fish from depth zone 3 rarely recaptured far from their tagging location (Fig. 5A; $\chi^{2}=20.7, P<0.001$ ). The proportion of recaptured fish that had dispersed from the tagging location increased with increased time at large (regression of proportion dispersers vs. years at large with years $14-19$ combined: $\mathrm{F}_{1,13}=30.2, P<0.001$ ). For all recaptured fish at large at least 10 years $(n=98)$, $15 \%$ were categorized as dispersers.

Dispersers tended to be smaller at initial capture than resident fish. This trend was significant for all fish combined (ANOVA: $F_{1,2559}=26.1, P<0.001$ ). For the smaller set of fish with known sex, the trend was significant for females $\left(F_{1,437}=21.4, P<0.001\right)$ but not for males $\left(F_{1,238}=0.6, P=0.453\right)$. In addition, within dispersers, smaller fish tended to migrate to greater distances than larger fish for all fish combined (Fig. 6; regres- sion: $F_{1,218}=15.6, P<0.001$, coefficient of determination $\left.\left[r^{2}\right]=0.07\right)$ as well as for females only $\left(F_{1,87}=11.6\right.$, $\left.P=0.001, r^{2}=0.11\right)$ and for males only $\left(F_{1,33}=7.2\right.$, $\left.P=0.011, r^{2}=0.16\right)$.

Fish that migrated away from the tagging area tended to move north and around the Pacific Rim (Fig. 7). Only $15 \%$ of the dispersers traveled south, and few of these moved more than $400 \mathrm{~km}$; the most southern recapture location was Bodega Canyon, California, a straight line distance of about $800 \mathrm{~km}$. Fish that traveled north and northwest were recaptured throughout the available geographic range of slope waters up to the western Aleutian Islands, and the most distant recaptures occurred near Tanaga Island, approximately $4000 \mathrm{~km}$ as straight line travel, but presumably far greater if fish travel along depth contours. Eight fish were recaptured on seamounts off the west coast of the United States and Canada (7 fish in the vicinity of Brown Bear and Cobb and 1 on Bowie). An effect of 


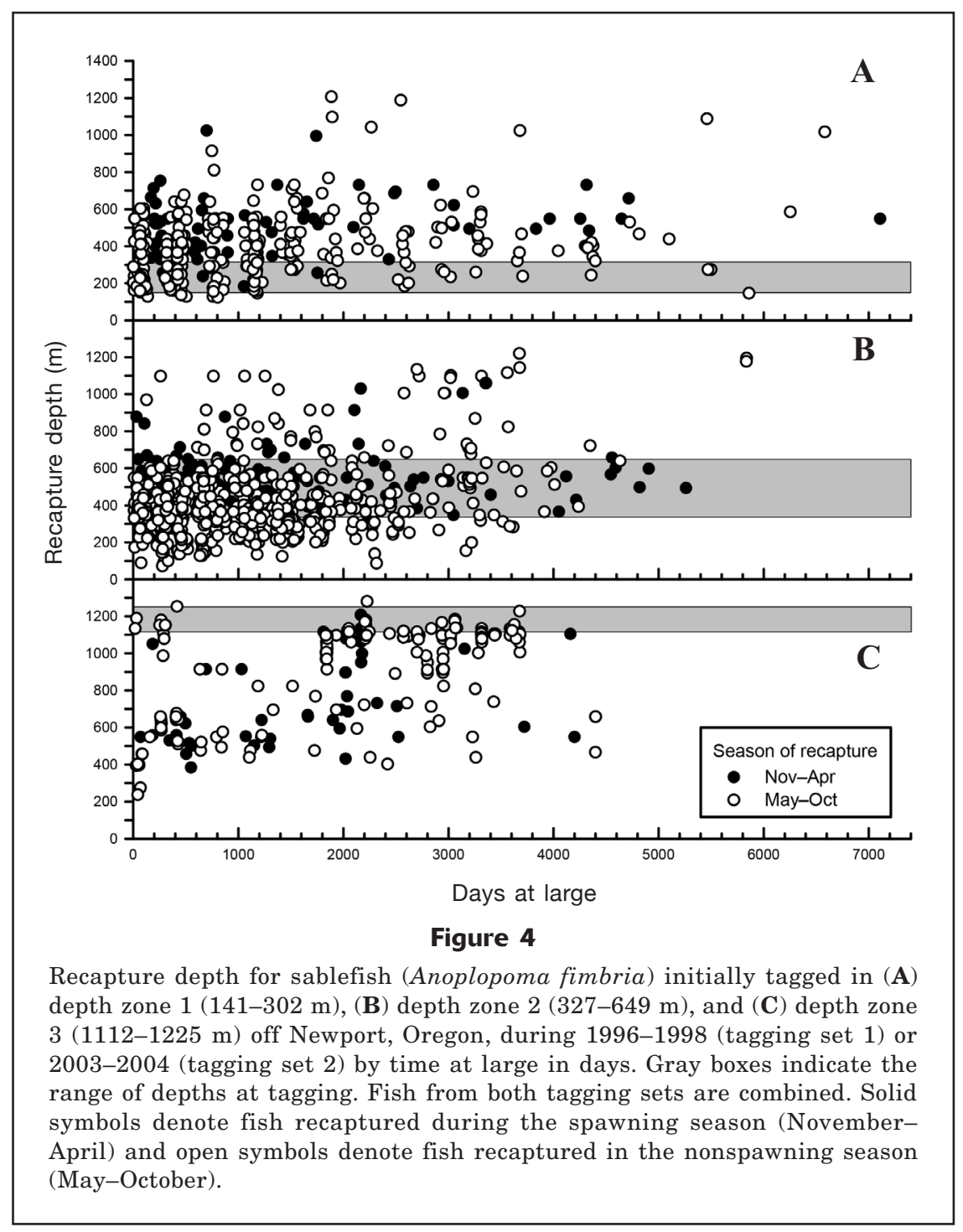

initial capture depth was also evident in the distance moved; no fish from depth zone 3 traveled farther than 700 km (Fig. 5B).

\section{Growth}

Recapture reports with information on sex, size, depth, and gear were available for 357 females and 181 males. Sample sizes by depth zone were 68, 188, and $101 \mathrm{fe}-$ males and 51, 108, and 22 males for depth zones 1 , 2 , and 3, respectively. Application of the full nonlinear regression model incorporating initial fish size, days at large, sex, initial capture depth, recapture depth, and recapture gear accounted for a substantial level of variation in growth $\left(r^{2}=0.79\right.$; Table 4$)$. All subset models excluding 1 or more parameters provided inferior explanatory power, with values of Mallows's $C_{p}$ far exceeding the number of parameters (all $\mathrm{C}_{\mathrm{p}}$ estimates $>30$ ), indicating that the full model was the best supported descriptor of the data (Table 5). To illustrate these effects we plotted growth estimates from the full model while setting the time at large to 1 year, recapture gear as fixed gear, and tagging and recapture depths as the midpoint of each depth zone. Growth increments were calculated separately by sex for the range of initial fish sizes observed for recaptured fish from each depth zone (Fig. 8). As expected, small fish grew faster than large fish, and females grew faster than males. Based on model estimates, growth rates were lower by $42 \%$ for males than for females. Growth also was substantially lower with increasing depth. Holding fish size constant and using the midpoint of each depth zone, we found that fish in zone 2 grew about $36 \%$ more slowly than fish in zone 1 . Growth rates of fish in zone 3 were reduced by $68 \%$ compared with growth rates of fish in zone 2 , and by $79 \%$ compared with growth rates of fish in zone 1. Fish recaptured in trawls had growth rates about $22 \%$ lower than those of fish recaptured by fixed 


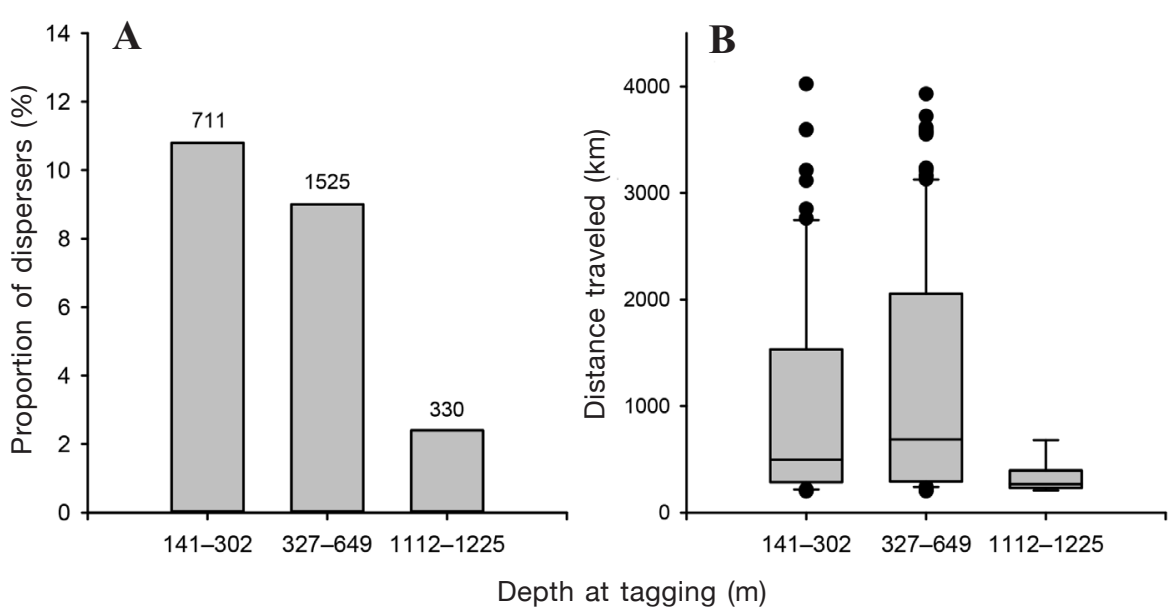

Figure 5

(A) Proportion of sablefish (Anoplopoma fimbria) that moved $>200 \mathrm{~km}$ from their tagging location (dispersers) for each of 3 depth zones at tagging off Newport, Oregon, during 1996-1998 (tagging set 1) or 2003-2004 (tagging set 2). Fish at large for $<1$ year were excluded. The number of recaptured fish with reliable location information is given above each bar. (B) Distance traveled (great circle distance between tagging and recapture location) by dispersing fish (exclusive of all residents, fish that moved $<200 \mathrm{~km}$ from their tagging location) for each depth zone at tagging. Box plots show median, $25^{\text {th }}$ and $75^{\text {th }}$ percentiles (box), $10^{\text {th }}$ and $90^{\text {th }}$ percentiles (whiskers), and outliers. Fish from both tagging sets are combined.

gear (data not shown). For fish of the sizes initially captured in this study, expected annual growth peaked at about 8-9 $\mathrm{cm} \mathrm{FL/year} \mathrm{for} \mathrm{small} \mathrm{females} \mathrm{and} 4-5 \mathrm{~cm}$ $\mathrm{FL} /$ year for small males in zone 1 , declining to $<2 \mathrm{~cm}$ FL/year for all fish of both sexes in zone 3 .

To determine whether fish that dispersed gained a growth advantage compared with fish that were residents, we applied ANOVAs to residuals from the nonlinear growth model, evaluating each sex separately. There was no difference in growth of female fish that dispersed and those that were residents (ANOVA: $\left.F_{1,355}=2.1, P=0.148\right)$. In contrast, males that dispersed had significantly faster growth rates than male residents $\left(F_{1,178}=6.0, P=0.015\right)$. In addition, for dispersed males, growth was positively correlated with the distance moved from the tagging location (regression: $\left.F_{1,26}=6.7, P=0.015\right)$. No relationship of growth with distance traveled was observed for female dispersers $\left(F_{1,67}=0.3, P=0.590\right)$.

\section{Discussion}

\section{Probability of recapture}

Recapture rates in this study were higher than those of prior studies of tagged sablefish, with $16.7 \%$ of fish in tagging set 1 and $13.7 \%$ of fish in tagging set 2 recaptured. High recapture rates reflect the extended recapture period (up to 20 years for tagging set 1 and 13 years for tagging set 2), and the low natural mortality rate for sablefish (Johnson et al. ${ }^{2}$ ). The probability of recapture increased with fish size, as observed in prior studies (McFarlane and Beamish, 1990; Saunders et al., 1990; McFarlane and Saunders, 1997). Stachura et al. (2012), in contrast, found no effect of fish size on likelihood of recapture in southeast Alaska, but $88 \%$ of their fish were $>60 \mathrm{~cm}$ FL. These patterns potentially reflect a nonlinear decrease in natural mortality rates with increasing fish size (e.g., Lorenzen, 1996).

The marked contrast in recapture rates between depth zones 2 and 3 of tagging set 2 was suggestive of a depth effect on discard mortality. However, this result was likely to be in part due to different fishing effort between depths. On the basis of logbook data reported to the Oregon Department of Fish and Wildlife, limited fishing effort occurred at depths $>900 \mathrm{~m}$ throughout the time period after tag deployment. Overall during the years 2004-2014, fish captured at depths $>900 \mathrm{~m}$ accounted for $5.3 \%$ of the total catch reported by trawl fisheries logbooks and $15.8 \%$ of fixed-gear fisheries. Although logbook compliance is not $100 \%$, these estimates clearly suggest fishing effort in deeper habitats was much lower than in shallower waters. Fish tagged in zone 3 tended to be recaptured later in the time series, in contrast with fish from zone 2 , which were recaptured at a steadily decreasing rate over the 13 postcapture years (Fig. 9). This contrast likely reflects increasing effort in deeper waters after 2008, particularly for fixed-gear fisheries. Based on depths of cap- 


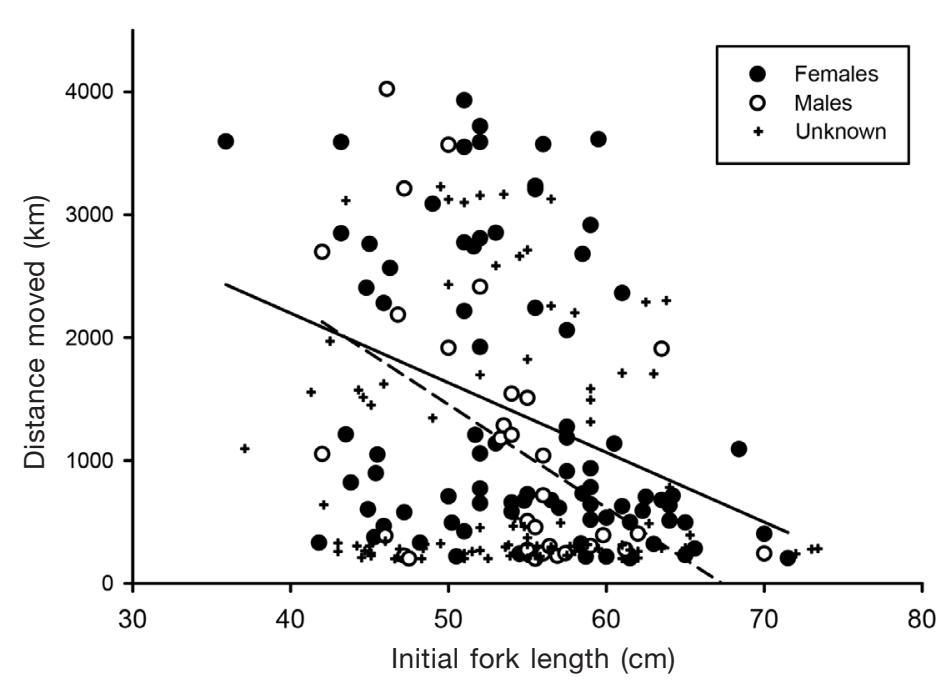

Figure 6

Relationship between initial size and distance moved (great circle distance between tagging and recapture location) for sablefish (Anoplopoma fimbria) initially captured off Newport, Oregon, during 1996-1998 (tagging set 1) or 2003-2004 (tagging set 2). Only fish that moved $>200 \mathrm{~km}$ from their tagging location and had reliable recapture locations are included. Regression lines were calculated separately for females (solid) and males (dashed). Fish from both tagging sets are combined.

captured at significantly lower rates under warmer surface temperatures than under cooler surface temperatures in depth zone 2. Although the difference was not significant in zone 3 , the overall recapture rate of small fish from zone 3 was very low (Table 3 ), limiting detectability of a temperature effect. No differences in recapture rates between surface temperatures were observed for medium or large fish at either depth. These size effects are consistent with prior laboratory studies. Observations of temperature-induced mortality were from experiments conducted primarily with fish $<55 \mathrm{~cm}$ FL, for which body core temperatures increased at a faster rate than those of larger fish after transfer to warm water (Davis et al., 2001). Davis and Parker (2004) also observed size-dependent effects on susceptibility to postcapture stressors.

\section{Implications of depth distribution}

Our results corroborate those of other studies that indicate low abundance of immature fish in deeper slope habitats (Jacobson et al., 2001; Maloney and Sigler, 2008). Fish in the 2 small size modes captured during initial sampling in depth zone 1 did not occur in depth zones 2 or 3 -a result con-

ture reported in logbooks and applied to total landings of sablefish in Oregon (all gears combined; Pacific Fisheries Information Network, website), annual landings in depths $>900 \mathrm{~m}$ were $<140 \mathrm{t}$ before 2009 , but $>220$ t during 2009-2013. Recapture rates after 2008 were $4.2 \%$ for fish tagged from zone 2 and $4.5 \%$ for fish tagged from zone 3 (after adjusting for removal of all previously recaptured fish). Thus, the low early recapture rates of fish tagged in zone 3 and the increasing recaptures after 2008 likely reflect patterns in overall fishing effort and therefore do not support a depth effect on discard mortality.

Recapture rates from the shallower end of the sablefish depth range may have been impacted by spatial closures. Offshore boundaries of the rockfish conservation areas varied spatially and temporally after their implementation in 2002 (Keller et al., 2014) and did not strictly match depth contours. In Oregon waters they were approximately $183 \mathrm{~m}$ (100 fm) for fixed gear and 274 to $457 \mathrm{~m}$ (150-250 fm) for bottom trawls from 2003 to present. Fish that were initially captured and remained after tagging in depth zones 1 and 2 would have continued to be vulnerable to fixed-gear fisheries but may have avoided trawl capture. The depth effect on probability of recapture for tagging set 1 , with reduced recaptures in depth zone 1 compared with depth zone 2, may have been influenced, in part, by lower fishing pressure in the shallowest habitats.

Surface temperatures appeared to influence discard mortality only for small fish $<55 \mathrm{~cm} \mathrm{FL}$, which were re- sistent with a pattern of settlement in relatively shallow water $(<300 \mathrm{~m})$. Recaptures of these smaller fish occurred throughout the slope depth gradient, with $38 \%$ occurring $>200 \mathrm{~m}$ deeper than the initial depth. Larger fish initially captured in zones 1 and 2 were likewise recaptured throughout the depth gradient, but only $17 \%$ were recaptured $>200 \mathrm{~m}$ deeper than their initial depth. For fish initially captured in depth zone $3,44 \%$ were recaptured at depths $>200 \mathrm{~m}$ shallower than their initial depth. These results provide only a snapshot view of depth-related movements because there is no information on depth distributions between capture and recapture. However, if recapture depths reflect general depth preferences over time, they suggest that most fish remained relatively close to their initial depths within the time frame covered by this study. For fish initially captured in zones 1 and 2, there was no greater likelihood for smaller fish to be recaptured at deeper depths than larger fish, counter to our expectation of ontogenetic movement. The significant effect of initial size on recapture depths for fish from zone 3 was also counter to expectations, with smaller fish more likely than larger fish to be recaptured in shallower depths.

Some of these patterns were potentially biased by fishing effort; for example, low effort in deep slope waters would limit our detection of fish that moved to those depths. The marked increase in recaptures after 2008 of fish initially tagged in depth zone 3 (Fig. 9) presumably reflected increased fishing effort. Recap- 


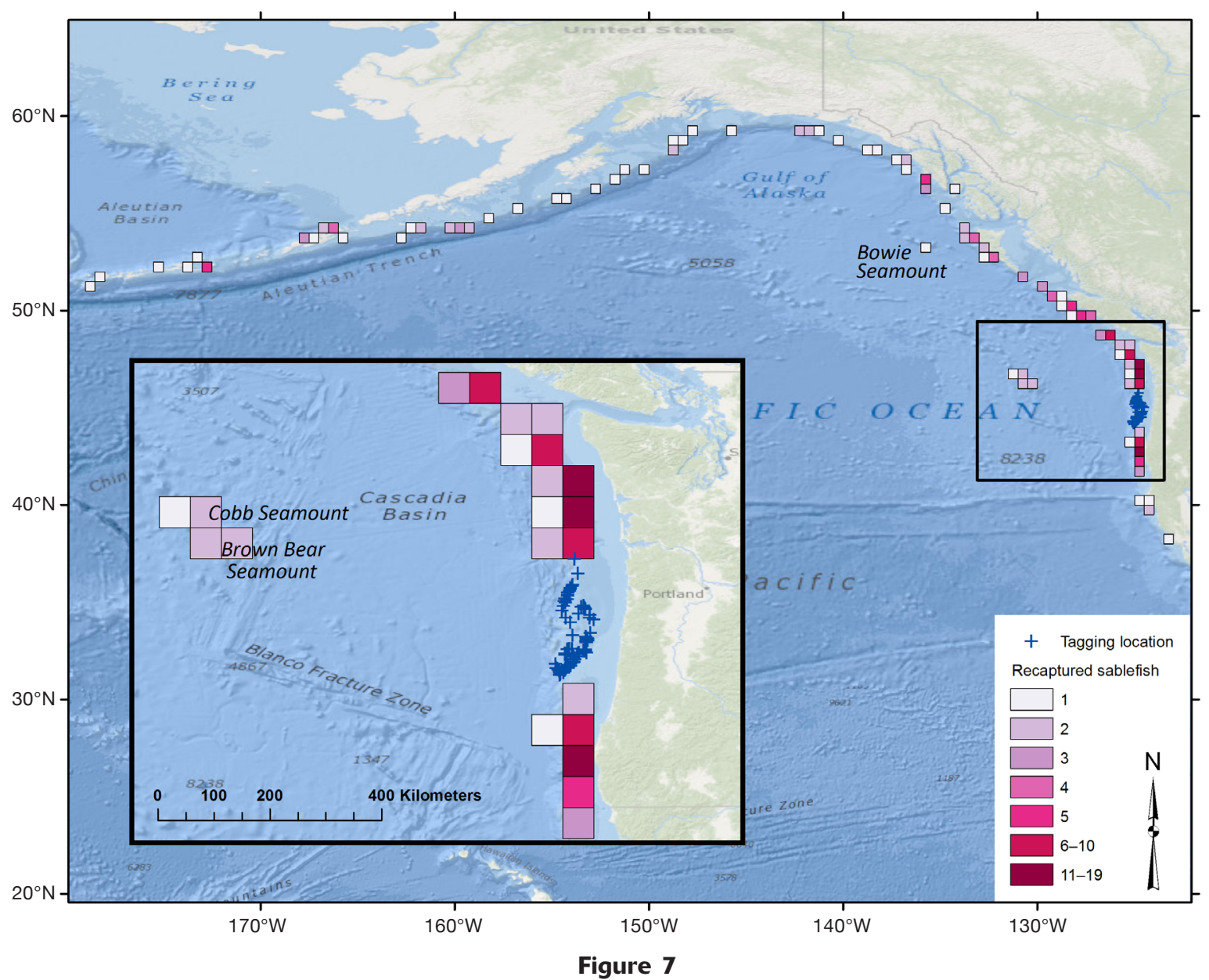

Location of all initial captures of sablefish (Anoplopoma fimbria) off Newport, Oregon, (blue crosses, inset map) and recapture locations of dispersers (fish that moved at least $200 \mathrm{~km}$ from their initial capture location) for the period 1996-2016. Recaptures are clustered into $0.5^{\circ}$ grids to mask exact capture locations. Recapture locations of fish categorized as residents, fish that moved $<200 \mathrm{~km}$ from their tagging location, are not shown. Fish from both tagging sets are combined.

ture rates in depths $>900 \mathrm{~m}$ for fish initially captured in zones 1 and 2 also increased in conjunction with the increased fishing effort starting in 2009, providing evidence of some movement to deep slope habitats. Approximately $13 \%$ of all fish initially captured in depth zones 1 and 2 and recaptured after 2008 were caught at depths $>900 \mathrm{~m}$.

Over a time frame of 1-2 decades, our results suggest settlement of sablefish to shelf habitats, then subsequent movement to a broad range of different depths along the slope. For females caught in trawl surveys of the southern stock, mean age increased with depth, but the spread of ages also increased, with fish at the deepest depths sampled ranging from 6 to 59 years old (Head et al., 2014, fig. 2), suggesting a pattern of early movement to a broad range of depths. The absence of older females at shallower depths noted by Head et al. (2014) could arise from several processes. Fish could be moving progressively deeper with time but at very slow rates, as suggested for Dover sole (Microstomus pacificus) by Hunter et al. (1990). Fish could also be acceler- ating their depth-related movement as they age, resulting in an accumulation of older fish in deeper habitats. Alternatively, higher mortality rates in shallow than in deep habitats, either natural or fishing induced, could reduce the life span of fish residing in upper slope areas. A depth-related decline in natural mortality rates would be consistent with the hypothesized longevity benefits of residence in or near the OMZ, whereas a depth-related decline in fishing mortality would be consistent with observed differences in effort by depth, potentially resulting in fishing-induced age truncation in the more heavily exploited shallower habitats.

Seasonal differences in recapture depths for fish from zones 1 and 2 indicated occurrence of sablefish in deeper waters during the potential spawning season (November-April) than during the nonspawning months of May-October. These depth differences were relatively minor; for all recaptures from zones 1 and 2 combined, mean depths were $122 \mathrm{~m}$ deeper in spawning than in nonspawning months. However, they do suggest movement to deeper waters as spawning begins. 


\section{Table 4}

Results of nonlinear regression for estimating recapture size of sablefish (Anoplopoma fimbria) as a function of initial size, time at large, sex, depth at initial capture, depth at recapture, and recapture gear. Growth data were available for 398 females and 203 males. Estimated parameter coefficients are listed along with their standard errors (SEs) and 95\% confidence intervals (CIs).

\begin{tabular}{lcccc}
\hline Parameter & Estimated coefficient & SE & Lower 95\% CI & Upper 95\% CI \\
\hline Initial size (fork length) & -0.002651 & 0.000098 & -0.002843 & -0.002459 \\
Time at large (days) & -0.000223 & 0.000016 & -0.000254 & -0.000193 \\
Sex (0=female, 1=male) & -0.539742 & 0.048204 & -0.634437 & -0.445048 \\
Initial depth & -0.001105 & 0.000108 & -0.001317 & -0.000893 \\
Recapture depth (m) & -0.000565 & 0.000090 & -0.000741 & -0.000389 \\
Recapture gear (0=fixed, 1=trawl) & -0.251627 & 0.049858 & -0.349570 & -0.153684 \\
& & & & \\
\hline
\end{tabular}

\begin{tabular}{|c|c|c|c|c|c|c|c|}
\hline \multicolumn{8}{|c|}{ Table 5} \\
\hline \multicolumn{8}{|c|}{$\begin{array}{l}\text { Coefficient of determination }\left(r^{2}\right) \text { and Mallows's } C_{p} \text { statistics for nonlinear regressions in } \\
\text { estimating recapture size of sablefish (Anoplopoma fimbria) as a function of models includ } \\
\text { ing 1-6 independent variables. The model with the highest } r^{2} \text { and lowest } \mathrm{C}_{\mathrm{p}} \text { values for } \\
\text { each subset number of input variables is noted with an } \mathrm{X} \text {, indicating variables included } \\
\text { in the model. }\end{array}$} \\
\hline \multirow{4}{*}{\multicolumn{2}{|c|}{$\begin{array}{c}\mathrm{C}_{\mathrm{p}} \\
r^{2}\end{array}$}} & \multicolumn{6}{|c|}{ Number of input variables } \\
\hline & & 6 & 5 & 4 & 3 & 2 & 1 \\
\hline & & 6.0 & 33.9 & 81.3 & 332.5 & 687.4 & 900.5 \\
\hline & & 0.789 & 0.776 & 0.756 & 0.693 & 0.577 & 0.503 \\
\hline \multicolumn{8}{|c|}{ Independent variable } \\
\hline Initial size & & $\mathrm{X}$ & $\mathrm{X}$ & $\mathrm{X}$ & $\mathrm{X}$ & $\mathrm{X}$ & $\mathrm{X}$ \\
\hline Sex & & $\mathrm{X}$ & $\mathrm{X}$ & $\mathrm{X}$ & $\mathrm{X}$ & $\mathrm{X}$ & \\
\hline Initial depth & & $\mathrm{X}$ & $\mathrm{X}$ & $\mathrm{X}$ & $\mathrm{X}$ & & \\
\hline Time at large & & $\mathrm{X}$ & $\mathrm{X}$ & $\mathrm{X}$ & & & \\
\hline Recapture depth & & $\mathrm{X}$ & $\mathrm{X}$ & & & & \\
\hline Recapture gear & & $\mathrm{X}$ & & & & & \\
\hline
\end{tabular}

For fish initially captured in depth zones 1 and 2, recapture depths indicated extensive movement within the upper slope region, but limited recaptures at depths within the OMZ. Only $10 \%$ of the total recaptures from zones 1 and 2 were at depths $>600 \mathrm{~m}$. Low oxygen environments may contribute to reduced growth rates but enhance longevity through reducing oxidation damage. Cailliet et al. (2001) found that within the speciose rockfishes (Sebastes spp.), deeper dwelling species had much longer life spans than shallower dwelling species. They suggested that the reduced metabolic rates of fish living in deep, low oxygen waters promote longevity by reducing exposure to oxidative stress. Thus, there may be a trade-off between growth and longevity for fish living above the OMZ in contrast with those fish living within it. This trade-off is suggested by the contrast between size and age distributions with depth observed for female sablefish by Head et al. (2014).

In our study, the sex ratio became increasingly biased toward females as depth increased, reaching $81 \%$ in depth zone $3(1112-1225 \mathrm{~m})$. Beamish et al. ${ }^{1}$ observed a further skewed sex ratio in extremely deep waters off British Columbia, with 93\% females in waters deeper than $1800 \mathrm{~m}$. On the basis of our results and those of Beamish et al. ${ }^{1}$ and Head et al. (2014), sablefish residing along the deep slope are primarily females with minimal growth, minimal propensity to disperse, and extended life spans. A disproportionate contribution of older or larger females to reproductive success has been documented for many long-lived species (Hixon et al., 2014). Rodgveller et al. (2016) found that older female sablefish in Alaska produced larger eggs and had an earlier start to the spawning season, although relative fecundity did not increase with age. In addition to these maternal effects on reproduction, there is clearly a potential for long life spans to buffer against longevity overfishing, or the removal of large numbers of older fish as described by Beamish et al. (2006). The relative inaccessibility and lower fishing effort in deep slope habitats suggests that they provide 


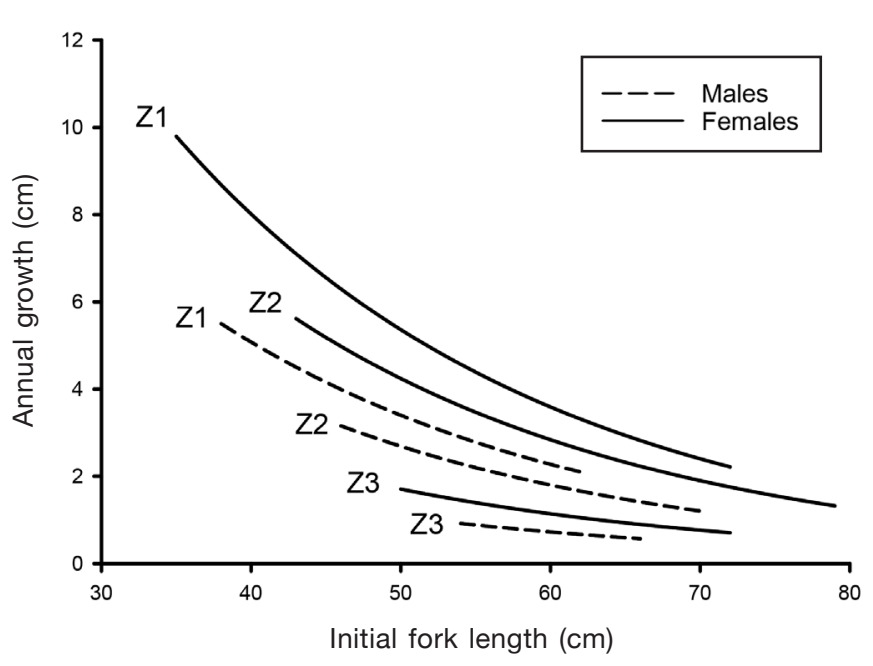

Figure 8

Estimated annual growth for male (dashed lines) and female (solid lines) sablefish (Anoplopoma fimbria) that resided in 3 depth zones (Z1=141-302 m, Z2=327-649 m, Z3=1112-1225 $\mathrm{m})$ when they were initially captured off Newport, Oregon, during 1996-1998 (tagging set 1) or 2003-2004 (tagging set 2 ). Growth estimates were derived from the full nonlinear regression model (Table 4) with time at large set at 365 days, depth at both tagging and recapture set at the mid-depth within each zone, and recapture gear set at fixed gear. For each depth zone, the range of fish sizes was restricted to that observed for recaptured fish with known sex. Fish from both tagging sets are combined.

a refuge in which females can survive and reproduce over many years, capitalizing on periodic environmental regimes favorable to larval survival and production of strong year classes.

\section{Implications of spatial movement patterns}

In contrast with the northern stock of sablefish, long distance movements were much less evident in Oregon fish and consistent with prior studies of the southern stock (Dark, 1983; Wespestad et al., 1983; Fujioka et al., 1988; Kimura et al., 1998). After 13 (2003-2004 tagging) to 20 (1996-1998 tagging) possible years at large, only $9 \%$ of all recaptured fish were taken from locations $>200 \mathrm{~km}$ from the tagging sites. Beamish and McFarlane (1988) found similar proportions of dispersers for fish tagged off Vancouver Island (fish that are likely to be part of the southern stock), but increasing dispersal for fish tagged off Haida Gwaii, Queen Charlotte Islands (fish that are likely to be part of the northern stock). The number of fish that dispersed from Oregon waters may have been underestimated if tag reporting differed by region. However, the nearly continuous geographic occurrence of recaptured dispersers across Alaska slope habitats (Fig. 7) and the high estimated levels of reporting, particularly in more recent years (Hanselman et al., 2015), suggest that Alaska fishermen are very cooperative in returning tags. Lower fishing effort and lower reporting rates in California waters may have resulted in reduced recovery of fish that moved south. For the years of possible recaptures in this study (1997-2016), sablefish landings in the California commercial fishery were on average $78 \%$ of the annual landings in Oregon (Pacific Fisheries Information Network, website). Because emigration rates appeared to increase over time and tag loss rates are cumulative, it is possible that some dispersers were not recognized because of tag loss. Overall, however, there was a clear tendency of Oregon fish to remain in Oregon waters, particularly for larger fish and fish residing in deeper habitats.

The fish that did disperse primarily traveled north and west, reaching almost to the farthest extent of U.S. waters in the western Aleutian Islands. Interestingly, dispersers from British Columbia waters also traveled primarily north into Alaska waters (Beamish and McFarlane, 1988). Although McFarlane and Saunders (1997) reported a number of recaptured fish in the Bering Sea for fish tagged in British Columbia waters, they did not report whether those fish were initially tagged off Haida Gwaii or Vancouver Island. Of the fish captured in Oregon waters in this study, none were recaptured in the Bering Sea.

There was an increased likelihood of migration with time at large, as with the results of Beamish and McFarlane (1988), but a few fish moved up to $2000 \mathrm{~km}$ within the first year after tagging, suggesting a high capacity and motivation for migration. The underlying reason for why some fish make extensive migrations, whereas others remain in the same general location for many years, is elusive. Morita et al. (2012) concluded that fish dispersing away from Bering Sea and Gulf of Alaska locations were mostly females that gained a growth advantage by migrating. We did not find a difference in growth between dispersing and resident females, but we did find a growth advantage for dispersing males. A propensity for dispersal may be related to individual differences in behavioral syndromes (Conrad et al., 2011). For example, intrapopulation differences in dispersal distances were found to be correlated with behavioral traits by Fraser et al. (2001) and Cote et al. (2010). Although dispersers are likely lost to their natal stocks, they maintain the metapopulation integrity of the species, and an extensive body of theory dating back to Hamilton and May (1977) argues for the fitness benefits of having some portion of a population disperse to different locations. This life history attribute of sablefish has clearly been successful considering their current geographic range.

\section{Growth}

Growth rates of recaptured fish generally matched previously observed patterns, with females growing faster than males, small fish growing faster than large fish, 


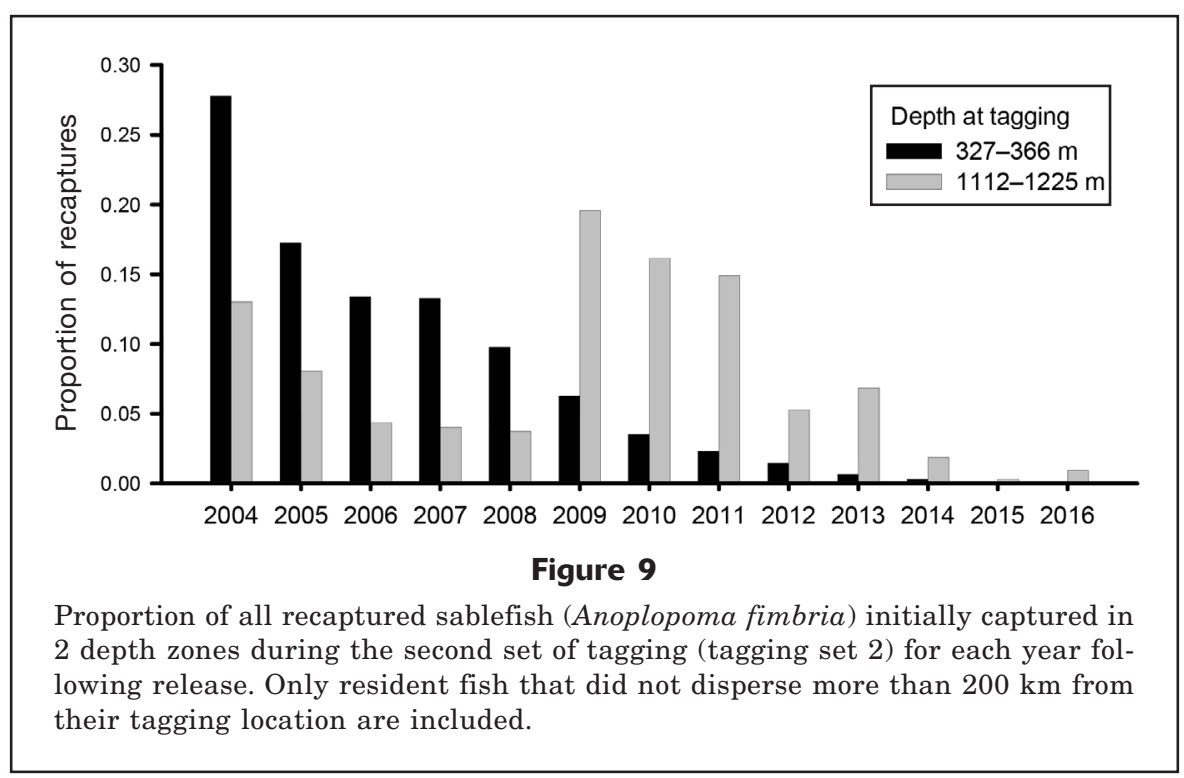

and growth rates overall slowing with time at large. Estimated growth rates of males in the full model were $42 \%$ lower than those of females. We were also able to document greatly reduced growth for fish of all sizes residing at deeper depths (zone 3 ). The depth effect on growth has been suggested by decreasing size at age with depth for both males and females (Saunders et al., 1997; Head et al., 2014) and verified here by recaptures of fish that presumably spent the time between tagging and recapture primarily near the depth of initial capture. Initial fish sizes of recaptured fish available for growth estimation from depth zone 3 ranged from 50 to $70 \mathrm{~cm} \mathrm{FL}$ for females and 54 to $66 \mathrm{~cm} \mathrm{FL}$ for malesa size range that includes immature individuals and fish not expected to be close to their asymptotic size. Our results corroborate those of Head et al. (2014), who found a marked decrease in asymptotic size with increased capture depth for female sablefish residing in west coast slope habitats from Cape Mendocino, California, to the U.S.-Canada border. Reduced growth at deeper slope habitats could arise from 2 different mechanisms. First, individual differences in genetically determined intrinsic growth rates could be associated with depths selected by fish after settlement such that fish with inherently lower growth capacity migrate to deeper habitats than those of fish capable of faster growth rates. Under this scenario, these individuals would have lower asymptotic sizes regardless of their habitat. Alternatively, reduced growth rates in deep slope waters could reflect environmental conditions of low temperature, low dissolved oxygen levels, and low productivity. Under this scenario, fish have lower asymptotic sizes because of a limited opportunity for growth; they are unable to attain the asymptotic sizes of fish residing at shallower depths. Although the latter, environmentally based mechanism is perhaps more intuitively appealing, contrasting intrinsic growth ca- pacity would be consistent with depth-dependent population structure as suggested by Fujiwara and Hankin (1988) and Norris (1997).

An additional factor influencing growth was the gear used at recapture; fish recaptured in fixed gear grew at faster rates than fish recaptured by trawls. Kimura et al. (1993) found a similar result and suggested a difference in selectivity between the 2 gear types. Sablefish actively entering baited traps or attacking bait on longlines may be more aggressive than fish captured passively by trawls. Individual differences in growth rates are often associated with behavioral differences in activity and boldness, potentially leading to differences in susceptibility to fishing gear (Biro and Post, 2008).

\section{Caveats}

As in any study of tag-recapture data that depend on tag returns primarily from commercial fishermen, there are several sources of potential error in interpretation of the resulting data. First, tag loss will result in recaptured fish not being identified. Prior studies of tag loss in sablefish with the use of double tag methods derived estimates of 0.02-0.03 for the instantaneous tag shedding rate per year (Beamish and McFarlane, 1988; Saunders et al., 1990; Lenarz and Shaw, 1997). Although these estimates are low compared with those reported for several other species (Lenarz and Shaw, 1997), over time the proportion of fish retaining their tag will decrease substantially. In our study, tag loss may have resulted in an underestimate of migration rates away from the tagging area over time, especially because the proportion of recaptured fish that were classified as dispersers increased over time. Second, geographic variation in reporting rates can influence interpretation of dispersal patterns. Reporting rates are thought to be consistently high in British Colum- 
bia waters but have varied widely over time and location within Alaska waters (Hanselman et al., 2015); they have not been estimated for the U.S. West Coast (California, Oregon, and Washington). Our results may have been biased toward higher or lower dispersal than indicated by tag returns, depending on spatial differences in reporting rates. Third, geographic or temporal variation in fishing effort can bias the interpretation of migration patterns. As noted above, the recently increased effort in deep slope waters off Oregon appeared to impact the temporal likelihood of recaptures from the deeper sites of tagging set 2 . However, recaptures in a nearly continuous contour along the slope from northern California to the Aleutian Islands reflect the geographic continuity of fishing effort throughout sablefish habitat. Finally, the tagging process in itself can impact fish biology. McFarlane and Beamish (1990) found that the presence of a Floy tag reduced growth and delayed maturity in sablefish. In our study, most of our comparisons were between different groups of tagged fish-comparisons that could be assumed to be valid if all were impacted similarly by the presence of a tag. Our calculated growth rates may have been underestimates, however.

Additional caveats concern the sampling design of our study. Fish were not collected and tagged from a broad region of depths between zones 2 and 3 (depths of $650-1110 \mathrm{~m}$ ). It is possible that some of our conclusions regarding depth-related movements could be modified if these depths had been included in sampling. In addition, with the growth model that we developed, there was the assumption of a smooth transition of growth rates from shallower to deeper habitats. It is possible that the decline in growth with depth instead follows a step function that matches transitions in habitat, such as those transitions associated with the OMZ or other parameters of habitat quality.

\section{Implications for management}

Our results concur with those of prior comparisons of northern and southern stocks of sablefish, particularly in the strong 'resident' behavior of Oregon fish. However, fish that did disperse often travelled thousands of kilometers away from Oregon, primarily into Gulf of Alaska waters. Within the northern stock there is extensive movement throughout the Gulf of Alaska and Bering Sea (summarized by Echave et al., 2013, and Hanselman et al., 2015), but there is more limited migration to waters within the range of the southern stock. Thus, overall, the 2 stocks are geographically distinct, which supports the current stock separation for management, but there is sufficient interchange to prevent genetic distinction. Because tagging studies to date have resulted in removal of fish from the population, movement patterns of individuals over their lifetimes and the extent to which dispersers return to the location of tagging are unknown. Likewise, movement patterns are unknown for the many fish that were caught near their tagging location after many years at large. It might be hypothesized that the northward dispersers in this study were northern fish that had made a temporary excursion to the south, but the dispersers tended to be smaller in size at tagging, suggesting they were spawned in Oregon. Future studies with archival and satellite tags (Echave et al., 2013) can provide insight into the extent to which fish make repeated movements from one region of the population to another. If the movement is a one-time event, then those fish will be lost to their respective stocks.

The recaptures from tagging set 2 indicated that warm surface temperatures may increase discard mortality rates for small fish. This outcome may be important in a management context because smaller fish are more likely to be discarded at sea in favor of retention of more valuable larger fish. Our results are likely to reflect a best case scenario, in which fish were captured by pots, carefully handled and released, and exposed to relatively moderate temperatures even in the high treatment $\left(15.3-17.8^{\circ} \mathrm{C}\right)$. Surface temperatures during extreme El Niño-Southern Oscillation conditions as well as those predicted with climate change will likely exceed those of our study. Effects of capture depth on discard mortality rates were confounded in our study with fishing effort. The reduced recapture rates from depth zone 3 in relation to depth zone 2 may have largely reflected the much lower fishing effort within depth zone 3, particularly during the initial post-tagging period. A more evenly balanced effort to recover tagged fish would be necessary to discern a depth effect on discard mortality.

The potential trade-off between growth and longevity along the slope depth gradient may be altered by future climate change effects, such as predicted increases in hypoxic conditions in coastal habitats and shoaling of the oxygen minimum layer (Pierce et al., 2012; Gilly et al., 2013). The capacity of sablefish to tolerate low oxygen conditions may benefit their future survival but at an unknown cost to individual growth rates. Low exploitation rates in very deep slope habitats may help to provide a spatial refuge, allowing accrual of the ecological benefits of a long life span.

\section{Acknowledgments}

T. Rippetoe assisted with tagging. R. Miller created the map of recapture locations. W. Satterthwaite provided statistics advice. N. Maloney, W. Mitton, K. Echave, S. Malvitch, S. Flores, and N. Wilsman assisted with recovery of recapture data. G. Hettman assisted with project design. M. Freeman provided Oregon Department of Fish and Wildlife data on fishery effort by depth. Funding was provided in part by NOAA Fisheries and the Pacific States Marine Fisheries Commission. We are indebted to the fishermen who provided the tagging cruises and to the crew of over 300 commercial fishing vessels who reported tag recaptures. We especially thank B. Eder for additional support in all aspects of this study. 


\section{Literature cited}

Beamish, R. J., and G. A. McFarlane.

1988. Resident and dispersal behavior of adult sablefish (Anoplopoma fimbria) in the slope waters off Canada's west coast. Can. J. Fish. Aquat. Sci. 45:152-164. Article 2000. Reevaluation of the interpretation of annuli from otoliths of a long-lived fish, Anoplopoma fimbria. Fish. Res. 46:105-111. Article

Beamish, R. J., G. A. McFarlane, and A. Benson.

2006. Longevity overfishing. Prog. Oceanogr. 68:289-302. Article

Biro, P. A., and J. R. Post.

2008. Rapid depletion of genotypes with fast growth and bold personality traits from harvested fish populations. Proc. Natl. Acad. Sci. U.S.A. 105:2919-2922. Article

Boehlert, G. W., and M. M. Yoklavich.

1985. Larval and juvenile growth of sablefish, Anoplopoma fimbria, as determined from otolith increments. Fish. Bull. 83:475-481.

Cailliet, G. M., A. H. Andrews, E. J. Burton, D. L. Watters, D.

E. Kline, and L. A. Ferry-Graham.

2001. Age determination and validation studies of marine fishes: do deep-dwellers live longer? Exp. Geront. 36:739-764. Article

Carton, J. A., B. S. Giese, and S. A. Grodsky.

2005. Sea level rise and the warming of the oceans in the Simple Ocean Data Assimilation (SODA) ocean reanalysis. J. Geophys. Res. Oceans 110:C09006. Article

Conrad, J. L., K. L. Weinersmith, T. Brodin, J. B. Saltz, and A. Sih.

2011. Behavioural syndromes in fishes: a review with implications for ecology and fisheries management. J. Fish. Biol. 78:395-435. Article

Cote, J., S. Fogarty, K. Weinersmith, T. Brodin, and A. Sih. 2010. Personality traits and dispersal tendency in the invasive mosquitofish (Gambusia affinis). Proc. R. Soc., B 277:1571-1579. Article

Dark, T. A.

1983. Movement of tagged sablefish released at abundance index sites off southeastern Alaska, Washington, Oregon, and California during 1978-81. In Proceedings of the International Sablefish Symposium; Anchorage, AK, 29-31 March. Alaska Sea Grant Rep. AK-SG-83-08, p. 143-146. Univ. Alaska, Fairbanks, AK.

Davis, M. W., and S. J. Parker.

2004. Fish size and exposure to air: Potential effects on behavioral impairment and mortality rates in discarded sablefish. North Am. J. Fish. Manage. 24:518-524.

Davis, M. W., B. L. Olla, and C. B. Schreck.

2001. Stress induced by hooking, net towing, elevated sea water temperature and air in sablefish: lack of concordance between mortality and physiological measures of stress. J. Fish. Biol. 58:1-15. Article

Drazen, J. C.

2007. Depth related trends in proximate composition of demersal fishes in the eastern North Pacific. Deep-Sea Res., part I, vol. 54:203-219. Article

Echave, K. B., D. H. Hanselman, M. D. Adkison, and M. F. Sigler.

2012. Interdecadal change in growth of sablefish (Anoplopoma fimbria) in the northeast Pacific Ocean. Fish. Bull. 110:361-374.
Echave, K. B., D. H. Hanselman, and N. E. Maloney.

2013. Report to industry on the Alaska sablefish tag program, 1972 -2012. NOAA Tech. Memo. NMFS-AFSC-254, $47 \mathrm{p}$.

Francis, R. I. C. C.

1995. An alternative mark-recapture analogue of Schnute's growth model. Fish. Res. 23:95-111. Article

Fraser, D. F., J. F. Gilliam, M. J. Daley, A. N. Le, and G. T. Skalski.

2001. Explaining leptokurtic movement distributions: intrapopulation variation in boldness and exploration. Am. Nat. 158:124-135. Article

Fujioka, J. T., F. R. Shaw, G. A. McFarlane, T. Sasaki, and B. E. Bracken.

1988. Description and summary of the Canadian, Japanese, and U.S. joint data base of sablefish tag releases and recoveries during 1977-1983. NOAA Tech. Memo. NMFS F/NWC-137, $34 \mathrm{p}$.

Fujiwara, S., and D. G. Hankin.

1988. Sex ratio, spawning period, and size and age at maturity of sablefish Anoplopoma fimbria off northern California. Nippon Suisan Gakkaishi 54:1333-1338.

Gilly, W. F., J. M. Beman, S. Y. Litvin, and B. H. Robison.

2013. Oceanographic and biological effects of shoaling of the oxygen minimum zone. Annu. Rev. Mar. Sci. 5:393-420. Article

Hamilton, W. D., and R. M. May.

1977. Dispersal in stable habitats. Nature 269:578-581. Article

Hanselman, D. H., J. Heifetz, K. B. Echave, and S. C. Dressel. 2015. Move it or lose it: movement and mortality of sablefish tagged in Alaska. Can. J. Fish. Aquat. Sci. 72:238-251. Article

Hart, J. L.

1973. Pacific fishes of Canada. Fish. Res. Board Can. Bull. 180, $740 \mathrm{p}$

Head, M. A., A. A. Keller, and M. Bradburn.

2014. Maturity and growth of sablefish, Anoplopoma fimbria, along the U.S. West Coast. Fish. Res. 159:56-67. Article

Heyamoto, H., and M. S. Alton.

1965. Distribution, abundance and size of sablefish (Anoplopoma fimbria) found in deep water off the mouth of the Columbia River. Commer. Fish. Rev. 27:1-8.

Hixon, M. A., D. W. Johnson, and S. M. Sogard.

2014. BOFFFFs: on the importance of conserving oldgrowth age structure in fishery populations. ICES J. Mar. Sci. 71:2171-2185. Article

Hunter, J. R., B. J. Macewicz, and C. A. Kimbrell.

1989. Fecundity and other aspects of the reproduction of sablefish, Anoplopoma fimbria, in central California waters. CalCOFI Rep. 30:61-72.

Hunter, J. R., J. L. Butler, C. Kimbrell, and E. A. Lynn.

1990. Bathymetric patterns in size, age, sexual maturity, water content, and caloric density of Dover sole, Micros. tomus pacificus. CalCOFI Rep. 31:132-144.

Jacobson, L. D., J. Brodziak, and J. Rogers.

2001. Depth distributions and time-varying bottom trawl selectivities for Dover sole (Microstomus pacificus), sablefish (Anoplopoma fimbria), and thornyheads (Sebastolobus alascanus and $S$. altivelis) in a commercial fishery. Fish. Bull. 99:309-327.

Keller, A. A., W. W. Wakefield, C. E. Whitmire, B. H. Horness, M. A. Bellman, and K. L. Bosley.

2014. Distribution of demersal fishes along the US west 
coast (Canada to Mexico) in relation to spatial fishing closures (2003-2011). Mar. Ecol. Prog. Ser. 501:169-190. Article

Kimura, D. K.

2008. Extending the von Bertalanffy growth model using explanatory variables. Can. J. Fish. Aquat. Sci. 65:1879-1891. Article

Kimura, D. K., A. M. Shimada, and S. A. Lowe.

1993. Estimating von Bertalanffy growth parameters of sablefish Anoplopoma fimbria and Pacific cod Gadus macrocephalus using tag-recapture data. Fish. Bull. 91:271-280.

Kimura, D. K., A. M. Shimada, and F. R. Shaw.

1998. Stock structure and movement of tagged sablefish, Anoplopoma fimbria, in offshore northeast Pacific waters and the effects of El Niño-Southern Oscillation on migration and growth. Fish. Bull. 96:462-481.

Lenarz, W. H., and F. R. Shaw.

1997. Estimates of tag loss from double-tagged sablefish, Anoplopoma fimbria. Fish. Bull. 95:293-299.

Lorenzen, $\mathrm{K}$.

1996. The relationship between body weight and natural mortality in juvenile and adult fish: a comparison of natural ecosystems and aquaculture. J. Fish. Biol. 49:627642. Article

Macewicz, B. J., and J. R. Hunter.

1994. Fecundity of sablefish, Anoplopoma fimbria from Oregon coastal waters. CalCOFI Rep. 35:160-171.

Mallows, C. L.

1973. Some comments on $C_{p}$. Technometrics 15:661-675. Article

Maloney, N. E., and M. F. Sigler.

2008. Age-specific movement patterns of sablefish (Anoplopoma fimbria) in Alaska. Fish. Bull. 106:305-316.

Mason, J. C., R. J. Beamish, and G. A. McFarlane.

1983. Sexual maturity, fecundity, spawning, and early life history of sablefish (Anoplopoma fimbria) off the Pacific Coast of Canada. Can. J. Fish. Aquat. Sci. 40:2126-2134. Article

McFarlane, G. A., and R. J. Beamish.

1983. Biology of adult sablefish (Anoplopoma fimbria) in waters off western Canada. In Proceedings of the International Sablefish Symposium; Anchorage, AK, 29-31 March. Alaska Sea Grant Rep. AK-SG-83-08, p. 59-80. Univ. Alaska, Fairbanks, AK.

1990. Effect of an external tag on growth of sablefish (Anoplopoma fimbria), and consequences to mortality and age at maturity. Can. J. Fish. Aquat. Sci. 47:1551-1557. Article

McFarlane, G. A., and M. W. Saunders.

1997. Dispersion of juvenile sablefish, Anoplopoma fimbria, as indicated by tagging in Canadian waters. In Biology and management of sablefish, Anoplopoma fimbria: papers from the international symposium on biology and management of sablefish; Seattle, WA, 13-15 April 1993 (M. E. Wilkins and M. W. Saunders, eds.), p. 137-150. NOAA Tech. Rep. NMFS 130.

Morita, S. H., K. Morita, and A. Nishimura.

2012. Sex-biased dispersal and growth in sablefish (Anoplopoma fimbria) in the northeastern Pacific Ocean. Environ. Biol. Fish. 94:505-511. Article

Norris, J. G.

1997. Adaptive radiation and sablefish Anoplopoma fimbria. In Biology and management of sablefish, Anoplopoma fimbria: papers from the international symposium on biology and management of sablefish; Seattle, WA, 13-15 April 1993 (M. E. Wilkins and M. W. Saunders, eds.), p. 99-113. NOAA Tech. Rep. NMFS 130.

Olla, B. L., M. W. Davis, and C. B. Schreck.

1998. Temperature magnified postcapture mortality in adult sablefish after simulated trawling. J. Fish. Biol. 53:743-751. Article

Pierce, S. D., J. A. Barth, R. K. Shearman, and A. Y. Erofeev. 2012. Declining oxygen in the northeast Pacific. J. Phys. Oceanogr. 42:495-501. Article

Rodgveller, C. J., J. W. Stark, K. B. Echave, and P.-J. F. Hulson. 2016. Age at maturity, skipped spawning, and fecundity of female sablefish (Anoplopoma fimbria) during the spawning season. Fish. Bull. 114:89-102. Article

Rutecki, T., and E. Varosi.

1997. Migrations of juvenile sablefish, Anoplopoma fimbria, in southeast Alaska. In Biology and management of sablefish, Anoplopoma fimbria: papers from the international symposium on biology and management of sablefish; Seattle, WA, 13-15 April 1993 (M. E. Wilkins and M. W. Saunders, eds.), p. 123-130. NOAA Tech. Rep. NMFS 130

Sasaki, T.

1985. Studies on the sablefish resources in the North Pacific Ocean. Bull. Natl. Res. Inst. Far Seas Fish. 22:1-108.

Saunders, M. W., G. A. McFarlane, and R. J. Beamish.

1990. Factors that affect the recapture of tagged sablefish off the west coast of Canada. Am. Fish. Soc. Symp. 7:708-713.

Saunders, M. W., B. M. Leaman, and G. A. McFarlane.

1997. Influence of ontogeny and fishing mortality on the interpretation of sablefish, Anoplopoma fimbria, life history. In Biology and management of sablefish, Anoplopoma fimbria: papers from the international symposium on biology and management of sablefish; Seattle, WA, 13-15 April 1993 (M. E. Wilkins and M. W. Saunders, eds.), p. 81-92. NOAA Tech. Rep. NMFS 130

Shenker, J. M.

1988. Oceanographic associations of neustonic larval and juvenile fishes and dungeness crab megalopae off Oregon. Fish. Bull. 86:299-317.

Sigler, M. F., S. A. Lowe, and C. R. Kastelle.

1997. Area and depth differences in the age-length relationship of sablefish, Anoplopoma fimbria, in the Gulf of Alaska. In Biology and management of sablefish, Anoplopoma fimbria: papers from the international symposium on biology and management of sablefish; Seattle, WA, 13-15 April 1993 (M. E. Wilkins and M. W. Saunders, eds.), p. 55-63. NOAA Tech. Rep. NMFS 130 55-63.

Sigler, M. F., T. L. Rutecki, D. L. Courtney, J. F. Karinen, and M.-S. Yang.

2001. Young of the year sablefish abundance, growth, and diet in the Gulf of Alaska. Alaska Fish. Res. Bull. $8: 57-70$

Sogard, S. M.

2011. Interannual variability in growth rates of early juvenile sablefish and the role of environmental factors. Bull. Mar. Sci. 87:857-872. Article

Sogard, S. M., and B. L. Olla.

2001. Growth and behavioral responses to elevated tem- 
peratures by juvenile sablefish Anoplopoma fimbria and the interactive role of food availability. Mar. Ecol. Prog. Ser. 217:121-134. Article

Somers, K. A., M. Bellman, J. Jannot, N. Riley, and J. McVeigh. 2014. Estimated discard and catch of groundfish species in the 2013 U.S. west coast fisheries. NOAA Fisheries, NWFSC Observer Program, Seattle, WA. [Available from website.]

Stachura, M. M., C. R. Lunsford, C. J. Rodgveller, and J. Heifetz.

2012. Estimation of discard mortality of sablefish (Anoplopoma fimbria) in Alaska longline fisheries. Fish. Bull. 110:271-279.
Sullivan, K. M., and K. L. Smith Jr.

1982. Energetics of sablefish, Anoplopoma fimbria, under laboratory conditions. Can. J. Fish. Aquat. Sci. 39:1012-1020. Article

Tripp-Valdez, M. A., F. J. García-de-León, H. Espinosa-Pérez, and G. Ruiz-Campos.

2012. Population structure of sablefish Anoplopoma fimbria using genetic variability and geometric morphometric analysis. J. Appl. Ichthyol. 28:516-523.

Wespestad, V. G., K. Thorsen, and S. A. Mizroch.

1983. Movement of sablefish, Anoplopoma fimbria, in the northeastern Pacific Ocean as determined by tagging experiments (1971-80). Fish. Bull. 81:415-420. 